\title{
KATARZYNA ZIELIŃSKA Spór o sekularyzację. Od dominacji do negacji?
}

Refleksja nad funkcją i znaczeniem religii w życiu społecznym od wieków zajmowała poczesne miejsce w myśli europejskiej. Przez długi czas religia traktowana była jako element niezbędny dla funkcjonowania społeczeństwa i dopiero wiek XVIII - wraz z jego pochwała rozumu i odrzuceniem wszystkiego co metafizyczne i pozaempiryczne - zapoczatkowal krytyczna debatę na temat miejsca, a także roli religii i instytucji religijnych w spoleczeństwie. Większość myślicieli doby Oświecenia przewidywała zniknięcie religii $z$ areny życia spolecznego w bliższej lub dalszej przyszlości. Wszelkie metafizyczne orientacje miały zostać wyparte przez rozum ludzki, a społeczeństwa miały wyzwolić się spod świętego baldachimu.

W XIX w. przekonanie o niekompatybilności tradycyjnych religii i nowoczesnego społeczeństwa zyskało wielu nowych zwolenników, również wśród prekursorów nauk spolecznych ${ }^{2}$. Teorie sekularyzacji powstały na bazie oświeceniowej krytyki i dziewiętnastowiecznych sporów i staly się szczególnie popularne w latach sześćdziesiatych. Pomimo różnorodności zdań w kwestii: czym jest proces sekularyzacji, czy rzeczywiście ma miejsce, a jeżeli tak, to jakie sa jego źródła i konsekwencje, podejście to zyskało pozycję podstawowego modelu badawczego na polu nauk spolecznych, a na poczatku lat siedemdziesiatych wręcz status dogmatu teoretycznego.

${ }^{1}$ F. J. L e ch ne r: The Case Against Secularization: A Rebuttal. „Social Forces”. R. 69: $1991 \mathrm{nr} 4$ (June) s. 1103.

${ }^{2} \mathrm{M}$. H a m i $1 \mathrm{t}$ o n: The sociology of religion: theoretical and comparative perspectives. London 1995 s. 163. 
Od samego początku istniały spory na temat użyteczności pojęcia sekularyzacja $^{3}$, aplikowalności teorii i jej formalno metodologicznych podstaw. Niemniej jednak prawdziwa debata rozgorzała w latach osiemdziesiątych. Krytycy poddali w watpliwość eksplanacyjną i predykcyjną wartość modelu. Równocześnie, powolując się na różnorodne dane empiryczne pochodzące z poza Europy, zakwestionowano istnienie procesu sekularyzacji we współczesnych społeczeństwach. Wielu teoretyków pośpiesznie i bezkrytycznie zarzuciło teorię sekularyzacji, niemniej jednak, część badaczy, postrzegając duży potencjał wyjaśniający tej teorii, pokusila się o głębszą analizę, co zaowocowało zrewidowaniem jej niektórych założeń.

\section{Sekularyzacja jako model teoretyczny}

Istnieje wiele nieporozumień w kwestii określenia czym jest sekularyzacja. Sam termin znajduje zastosowanie w różnych dziedzinach nauki (filozofia, nauki społeczne, teologia, historia) i odnosi się do wielu różnorodnych zjawisk, co stanowi dodatkowa trudność przy próbie doprecyzowania jego zakresu pojęciowego. Co więcej, w europejskiej socjologii istnieje tendencja do zawężania znaczenia terminu sekularyzacja i stosowania go jedynie w odniesieniu do chrześcijaństwa, tak więc dla wielu teoretyków sekularyzacja jest synonimem dechrystianizacji. Bez wątpienia utożsamianie tych dwóch procesów jest konsekwencją faktu, iż teorie sekularyzacji narodziły się w europejskim kręgu kulturowymi w glównej mierze odnoszą się do zjawisk zachodzących w Europie ${ }^{4}$. Niemniej stanowisko takie wydaje się zbyt uproszczone, szczególnie w sytuacji gdy zarówno termin jak i pewne tezy modelu stosowane są w odniesieniu do procesów zachodzących w pozaeuropejskich kręgach kulturowych ${ }^{5}$. Termin sekularyzacja może być stosowany w jednoznaczny sposób jedynie, jeśli odnosi się do religii w sensie generalnym, a nie do jakiejś konkretnej jej formy. Warto podkreślić, iż sposób rozumienia religii ${ }^{6}$ często determinuje definiowanie czy też rozumienie pro-

${ }^{3}$ D. M a r t i n: The Religious and the Secular. Studies in Secularization. London 1969.

${ }^{4}$ G. D a v i e: Prospects for religion in The Modern World. „Ecumenical Review” 2000, October (on-line) issue:, s. 65 - dostępny: www.findarticles.com.

${ }^{5}$ E. P a c e: The Helmet and the Turban. Secularization in Islam. W: Secularization and Social Integration. Red. R. L a e r m a n s, B. W i l s o n, J. B i 11 i e t. Leuven 1998 s. 165.

${ }^{6}$ Definiowanie terminu religia wiąże się $\mathrm{z}$ wieloma problemami, a wielość definicji oddaje różnorodność zjawisk, które są określane mianem religii (G. Ke h r e r: Wprowadzenie do socjologii religii. Kraków $1997 \mathrm{~s} .21$; M. H a m il t o n: The sociology of religion: theoretical and comparative perspectives. London 1995 s. 166). 
cesu sekularyzacji, tym bardziej, iż brak w socjologii precyzyjnej, powszechnie obowiązującej definicji pojęcia sekularyzacja ${ }^{7}$.

\section{Rozumienie pojęcia sekularyzacja}

Punktem wyjścia w rozważaniach na temat pojęć jest - bez watpienia - rozróżnienie pomiędzy dwoma, często zamiennie używanymi terminami, a mianowicie pomiędzy sekularyzacja a sekularyzmem. Sekularyzacjq, najogólniej mówiąc, określany jest proces zmiany zachodzący w obrębie struktury społecznej, będący wynikiem interakcji różnorodnych czynników i procesów społecznokulturowych, które do pewnego stopnia zależą od działań poszczególnych jednostek $^{8}$. Zaś termin sekularyzm odnosi się do ideologii postulującej podjęcie aktywnych działań, których celem jest ograniczenie a nawet wyeliminowanie religii z życia społecznego ${ }^{9}$.

Samo pojęcie sekularyzacja używane jest w wielu znaczeniach; L. Shiner ${ }^{10}$ analizując bogatą literaturę przedmiotu wyróżnił sześć najpopularniejszych sposobów jego użycia. Termin sekularyzacja określa:

- proces podupadania religii, w wyniku którego wcześniej akceptowane religijne symbole, doktryny i instytucje traca prestiż i znacznie; końcowym efektem tego procesu byłoby powstanie społeczeństwa areligijnego;

- zmianę świadomości ludzi, zjawisko wzrastającego dostosowania się do tego świata, czego efektem jest odwrócenie się od elementów nadprzyrodzonych i skupienie się na realiach życia ziemskiego;

- uwolnienie społeczeństwa od religii, poprzez jej wycofanie do oddzielnej sfery; stając się domeną życia prywatnego, religia przestaje wpływać na pozostałe aspekty życia społecznego;

- proces, którego konsekwencją jest przekształcenie religijnych wierzeń i instytucji w formy niereligijne; wiedza, zachowania i instytucje, które kiedyś byly traktowane jako zakorzenione w mocy boskiej stają się zjawiskami o charakterze czysto ludzkim, efektem jest antropomorfizacja religii;

\footnotetext{
${ }^{7}$ Problem ten dotyczy w zasadzie większości pojęć stosowanych w naukach humanistycznych.

${ }^{8}$ B. Wils o n: The Secularization thesis: Criticisms and rebuttals. W: Secularization and Social Integration. Red. R. L a e r m a n s, B. W i l s o n, J. B i 11 i e t. Leuven 1998 s. 46.

${ }^{9}$ C. J. S o m m e rville: Secular Society/Religious Population: Our Tacit Rules for Using the Term »Secularization«. "Journal for the Scientific Study of Religion”. R. 37: $1998 \mathrm{nr} 2$ s. 251.

${ }^{10} \mathrm{M}$. H a m i $1 \mathrm{t}$ o n: The sociology of religion: theoretical and comparative perspectives, $\mathrm{dz}$. cyt., s. 166
} 
- desakralizację świata, który traci swój sakralny charakter, podczas gdy człowiek i natura stają się przedmiotem swobodnej, racjonalnej interpretacji i manipulacji;

- proces przejścia od społeczeństwa „uświęconego" do świeckiego w sensie zerwania z tradycyjnymi wartościami i praktykami, w wyniku czego wszelkie decyzje i dzialania zostaja oparte na racjonalnych i utylitarnych przesłankach; w tym znaczeniu termin sekularyzacja jest stosowany w szerszym rozumieniu i odnosi się nie tylko do zmiany roli religii w życiu społecznym, ale również do innych fenomenów.

Powyższa analiza doskonale obrazuje wieloznaczność i różnorodność zjawisk, do których odnosi się termin sekularyzacja. Brak zgody pomiędzy teoretykami co do jednoznacznego użycia terminu, wywołał falę krytyki, konsekwencja której była propozycja całkowitego wyeliminowania go $\mathrm{z}$ nauk społecznych ${ }^{11}$. Propozycja taka wydaje się jednak przedwczesna. Sedno znaczenia terminu sekularyzacja odnosi się do ograniczenia wplywu specyficznych religijnych instytucji i wierzeń, co obejmuje swym zakresem większość proponowanych przez Shiner'a znaczeń, ponadto termin ten odnosi się do empirycznie uchwytnych procesów, posiadających duże znacznie dla nowoczesnej historii Zachodu. Bardziej zasadny wydaje się postulat doprecyzowania pojęcia, tym bardziej, iż analogiczne zarzuty mogłyby być wysunięte w kierunku wielu innych pojęć i terminów stosowanych w naukach społecznych.

\section{Teorie sekularyzacji}

Trudność w dyskusji na temat sekularyzacji wynika $z$ wielości koncepcji teoretycznych, które określane sa mianem teorii sekularyzacji. Nawet pobieżna prezentacja niektórych tylko propozycji pozwala zauważyć, iż poszczególni autorzy akcentuja różne aspekty procesu sekularyzacji, choć niewatpliwie wspólnym mianownikiem jest przekonanie o istnieniu zmiany zarówno charakteru relacji jak i wzajemnego oddziaływania religii i społeczeństwa. Na przykład jeden $z$ najbardziej wpływowych socjologów religii - P. Berger ${ }^{12}$, określa mianem sekularyzacji proces, w wyniku którego poszczególne sektory spoleczeństwa i kultury sa wyzwalane spod dominacji instytucji i symboli religijnych. Sekularyzacja zachodzi w obrębie struktury i instytucji społecznych, kultury a również na poziomie jednostkowym - coraz więcej osób patrzy na świat bez stosowania religijnej interpretacji rzeczywistości. Czynnikiem odpowiedzialnym za pojawienie się sekularyzacji jest proces racjonalizacji, ściśle związany z tradycją judeochrześcijańska.

${ }^{11}$ D. M a r t i n: The Religious and the Secular. Studies in Secularization, dz. cyt., s. 9.

${ }^{12}$ P. B e r g e r: Święty Baldachim. Kraków 1997 s. 150. 
Dla B. Wilsona, sekularyzacja jest procesem społecznym, występującym w organizacji społeczeństwa, w kulturze i w kolektywnej mentalności jednostek. Konsekwencją nie musi być całkowite zniknięcie religii z życia społecznego, ani powstanie populacji areligijnych ludzi, choć zmniejszajaca się społeczna rola religii nie pozostaje bez wpływu na religijność jednostek ${ }^{13}$. Zależności występujące pomiędzy obydwoma poziomami nie sa jednoznaczne i jednokierunkowe. Jednym z czynników warunkujących zaistnienie procesu sekularyzacji jest wzrastające znaczenie nauki i jej wpływ na eliminowanie religijnej interpretacji świa$\mathrm{ta}^{14}$. Ważną rolę odegrała tu zmiana organizacji spoleczeństwa, będąca konsekwencją modernizacji: przejście od społeczności (community) - gdzie kontrola spoleczna jest oparta na religii i moralności do spoleczeństwa (society) - zorganizowanego na bazie racjonalnych zasad. Wiąże się z tym różnicowanie i specjalizacja instytucji ${ }^{15}$.

S. Bruce ${ }^{16} z$ kolei określa mianem sekularyzacji ograniczenie znaczenia religii dla funkcjonowania pozareligijnych ról i instytucji (np. ekonomii i państwa), obniżenie społecznej pozycji instytucji i ról religijnych, a na poziomie jednostki - zmniejszanie się zakresu, w jakim ludzie są zaangażowani w praktyki religijne i stopnia, w jakim wiara religijna wpływa na ich życie. Wyjątkiem jest przypadek, gdy religia nie jest jedynie systemem odniesienia jednostki do sił nadprzyrodzonych, ale wypełnia również dodatkowe role - np. obrony kultury lub kulturowej zmiany.

Jedną z najbardziej koherentnych propozycji teoretycznych zaproponował D. Martin. Jego teoria sekularyzacji, to próba opisu zmiany roli, sily i popularności religijnych wierzeń i instytucji. Proponuje on podejście, będące teorią empiryczną, która odnosi się do zjawisk zachodzących w Europie, będących konsekwencją historycznych uwarunkowań i związku pomiędzy państwami europejskimi i religia ${ }^{17}$. Autor próbuje wykazać zależność specyfiki procesu sekularyzacji od konkretnego kontekstu kulturowego i historycznego: proces ten wygląa inaczej w krajach protestanckich, katolickich i mieszanych, a zatem przypadek każdego kraju wymaga osobnej analizy.

${ }^{13}$ B. Wi 1 s o n: The Secularization thesis: Criticisms and rebuttals, dz. cyt., s. 49 i 63.

${ }^{14}$ B. Wi 1 s o n: Secularization: The Inherited Model. W: The Sacred in a Secular Age. Toward Revision in the Scientific Study of Religion. Red. P. E. H a m m o n d. Berceley, Los Angeles and London 1985 s. 13.

${ }^{15} \mathrm{~B}$. Wils o $\mathrm{n}-\mathrm{za}$ M. H a m i $1 \mathrm{t}$ o $\mathrm{n}$ : The sociology of religion: theoretical and comparative perspectives. London 1995 s. 173.

${ }^{16} \mathrm{~S}$. B r u c e: God is Dead. Secularization in the West. Balckwell Publishing 2002 s. 3.

${ }^{17}$ D. M a r t i n: A General Theory of Secularization. Gregg Revivals. Hampshire 1993 s. 2. 
Nawet pobieżne zaprezentowanie zasadniczych punktów koncepcji najbardziej wplywowych autorów pozwala na zaobserwowanie różnic w rozumieniu procesu sekularyzacji. Pomimo to uzasadnione wydaje się uogólnienie, iż teorie sekularyzacji opisuja czynniki warunkujące proces sekularyzacji i jego przebieg.

\section{Sekularyzacja jako paradygmat przemian religijnych}

Analiza poszczególnych teorii pozwala na wyłonienie wielu punktów wspólnych i uprawnia do mówienia o istnieniu paradygmatu sekularyzacji. $\mathrm{Na}$ poparcie tej tezy można przytoczyć próbę systematyzacji zagadnień związanych z sekularyzacją, której podją się $O$. Tschennen. Analizując prace teoretyków zajmujących się tym tematem, wyróżnił trzy elementy czy też procesy, które konstytuują paradygmat sekularyzacji, a mianowicie „różnicowanie”, „racjonalizacja” i „koncentracja na życiu doczesnym”. Ponieważ poszczególne propozycje różnią się pod wieloma względami na poziomie teoretycznym, niemożliwe wydaje się skonstruowanie jednej meta-teorii, niemniej jednak, ze względu na to, że podzielają one takie same ogólne założenia i kategorie analityczne, można mówić o istnieniu spójności na poziomie paradygmatycznym ${ }^{18}$.

Interesująca próbę usystematyzowania zagadnień związanych z sekularyzacją podją K. Dobbelaere. Analizując prace licznych teoretyków i biorąc pod uwagę zarówno źródła jak i konsekwencje procesu sekularyzacji, zaproponował wielowymiarowy model opisowy. Autor wyróżnił trzy poziomy analizy tego zjawiska, a mianowicie makro, meso i mikro. Sekularyzacja w odniesieniu do zmian zachodzących na poziomie makro, określana mianem laicyzacji, oznacza desakralizację i proces różnicowania się instytucji społecznych, w wyniku czego religia staje się jednym $z$ wielu elementów systemu społecznego. Na tym poziomie sekularyzacja nie oznacza zmniejszenia się obecności religii, ale stanowi wyzwanie dla jej dotychczasowego społecznego wpływu. Innymi słowy efektem jest nie tyle zanik religii, co wyeliminowanie jej ze sfery publicznej i zepchnięcie do sfery prywatnej. Na poziomie meso termin ten odnosi się do zmiany religijnej, która w głównej mierze jest konsekwencją zaistnienia pluralizmu religijnego i pojawienia się rynku wartości. Organizacje religijne mogą tracić zainteresowanie sprawami religijnymi i porzucać swoje dotychczasowe religijne funkcje, czego konsekwencją może być również upadanie starych i pojawianie się nowych form religijnych. Na poziomie mikro, a więc indywidualnym, sekularyzacja odnosi się do zachowań jednostki i mierzy w jakim stopniu są one zintegrowane z normatywnym postulatami danej religii. Sekularyzacja na poziomie indywidualnym związana jest ściśle ze zjawiskiem indywidualizacji religii, które

${ }^{18}$ O. T s ch a n n e n: The Secularization Paradigm: A Systematization. „Journal for the Scientific Study of Religion”. R. 30: 1991 nr 4 s. 400. 
polega na konstruowaniu prywatnej, indywidualnej religii pozostającej w luźnym związku $z$ dogmatycznymi i instytucjonalnymi formami religijności ${ }^{19}$.

Zaproponowany przez Dobbelaere'a model doskonale pokazuje zlożoność procesu sekularyzacji. Dokladne zbadanie licznych aspektów tego procesu, wymaga podjęcia analiz na różnych etapach, a pojawiające się pomiędzy poszczególnymi poziomami powiązania, mogą okazać się wielokierunkowe a nawet wewnętrznie sprzeczne. Na przykład sekularyzacja na poziomie społeczeństwa, rozumiana jako istnienie zróżnicowanych, wyspecjalizowanych i zlaicyzowanych struktur, funkcjonujących według zasad diametralnie innych niż religijne, nie implikuje istnienia zeświecczonej populacji ${ }^{20}$. Ilustracją takiego zjawiska moga być Stany Zjednoczone z konstytucyjnym rozdziałem religii od państwa, czego konsekwencją jest wyzwolenie sfery publicznej od wpływu jakiejkolwiek religii, gdzie dominująca część populacji charakteryzuje się wysokim poziomem religijności i gdzie istnieją różnorodne, aktywnie działające organizacje religij$\mathrm{ne}^{21}$. Odwrotną zależność można zaobserwować we wspólczesnej Skandynawii, gdzie religia, poprzez formalne związki pomiędzy Kościolem i państwem, jest wciąż obecna w strukturach społecznych, pomimo szeroko rozpowszechnionej sekularyzacji społeczeństwa ${ }^{22}$.

Pomiędzy poszczególnymi poziomami procesu sekularyzacji może istnieć pewien stopień niezależności, błędne byłoby jednak przypuszczenie, iż poszczególne jego aspekty pozostają bez wzajemnego wpływu. S. Acquaviva ${ }^{23}$ sugeruje na przykład, iż modernizacja, a więc zmiany struktury społecznej, różnicowanie się i specjalizacja poszczególnych systemów, wygenerowała nowy rodzaj poznania, który pod wpływem mediów stał się fenomenem spolecznym, eliminującym prelogiczne, a zatem również religijne poglądy. Istnieje również przypuszczenie, iż pojawienie się zjawisk określanych mianem religia a la carte (wybieranie $\mathrm{z}$ danej tradycji religijnej tylko niektórych elementów i odrzucanie innych) i religijny bricolage (mieszanie elementów różnych tradycji religijnych) wiąże się -

${ }^{19}$ K. D o b b e l a e r e: Secularization: a multi-dimensional concept. Current Sociology. R. 1981: 29 nr 2 (Summer) s. 3-215; K. Dobbelaere: Towards an Integrated Perspective of the Processes Related to the Descriptive Concept of Secularization. „Sociology of Religion” 1999 (on-line) Issue: Fall - dostępny: www.findarticles.com.

${ }^{20}$ T e $\mathrm{n}$ z e: Towards an Integrated Perspective of the Processes Related to the Descriptive Concept of Secularization, 1999.

${ }^{21}$ P. B e y e r: Sociological theory of religion between description and prediction. W: Secularization and Social Integration: A Weberian question revisited. Red. R. L a e r m a n s, B. W i 1 s o n, J. Bill i e t. Leuven 1998 s. 99.

${ }^{22}$ E. Christiansen: Is the Lutheran Church still the state church? An analysis of Church-State relations in Finland. BYULR. R. 1995 nr 2 s. 40.

${ }^{23} \mathrm{Za}-\mathrm{K}$. D o b b e l a e r e: Towards an Integrated Perspective of the Processes Related to the Descriptive Concept of Secularization, dz. cyt. 
w pewnym stopniu - z upadkiem autorytetu Kościołów, podważającym obiektywizm i jedność chrześcijańskiej, kolektywnej świadomości Zachodu. Jednocześnie obserwowalna współcześnie zmiana wyobrażenia sacrum, z osobowego Boga na bezosobową siłę, czy moc, jest tłumaczona upadkiem tradycyjnego community i powstaniem spoleczeństwa miejskiego ${ }^{24}$.

Niewątpliwie związki pomiędzy poszczególnymi poziomami procesu sekularyzacji wymagają dalszej wnikliwej analizy, ale samo rozróżnienie trzech wymiarów uściśla model i jest użyteczne ze względu na możliwość empirycznej weryfikacji teorii.

\section{Krytyka teorii sekularyzacji}

W latach osiemdziesiątych model sekularyzacji został mocno skrytykowany. Argumenty wysuwane w dyskusji odnosiły się do różnych aspektów, a najczęściej kwestionowano naukową rzetelność teorii i ich sprzeczność z danymi empirycznymi.

\section{Krytyka podstaw metodologicznych}

Metodologiczne założenia teorii sekularyzacji zostały poddane krytyce. Zarzucano im brak ścisłości strukturalno-formalnej, a także podważono wartość opisową i predyktywną całego podejścia. ${ }^{25}$ Jednym z podstawowych zarzutów było twierdzenie, iż model sekularyzacji nie stanowi zwartego systemu teoretycznego. Według J. Hadden'a skrupulatne badanie pokazuje, że nie ma niczego takiego jak teoria sekularyzacji, która nigdy nie została systematycznie wyrażona czy empirycznie zweryfikowana, jest jedynie „mieszaniną luźnie powiązanych idei" i stanowi raczej rodzaj ideologii, czy doktryny ${ }^{26}$. Hadden stosujac quasipozytywistyczne standardy oczekuje od teorii sekularyzacji, aby sformułowana została jako systematyczny zbiór powiązanych i testowanych twierdzeń, popartych dowodami empirycznymi. Standardy takie sa jednak trudne do spełnienia, szczególnie w zastosowaniu do teorii w naukach humanistycznych, które jedynie sporadycznie dają się przedstawić w postaci dedukowalnych i logicznie zwartych

\footnotetext{
${ }^{24}$ Tamże.

${ }^{25} \mathrm{~W}$ pracach z zakresu metodologii podkreśla się iż teoria empiryczna winna wypełnić trzy funkcje: deskryptywną (opisujaca), eksplanacyjną (wyjaśniająca) i predyktywną (prognostyczna). Warstwa opisowa teorii zawiera opisy obserwowalnych faktów, które to opisy mogą być mniej lub bardziej ogólne. Warstwa wyjaśniająca zawiera twierdzenia o związkach funkcjonalnych zachodzących między faktami, zaś warstwa trzecia wynika z dwóch poprzednich. (K. B. M a d s e n: Wspótczesne teorie motywacji. Warszawa 1980 s. 10).

26 J. K. H a d d e n: Toward Desacralizing Secularization Theory. „Social Forces”. R. 1987: 65 nr 3 (March) s. 598.
} 
systemów teoretycznych. Co więcej, większość istniejących w naukach społecznych teorii nie spełnia tak ścislych kryteriów metodologicznych, co wynika ze specyfiki zjawisk społecznych, charakteryzujących się znacznie większą różnorodnością i zmiennościa, niż fakty empiryczne, w oparciu o które na bazie których budowane są teorie w naukach ścislych. Nie ma żadnego powodu dla którego nie mielibyśmy mówić o naukach nieścisłych, - jak słusznie zauważa S. Andreski - ponieważ - tak jak w przypadku innych jakości - ścisłość i dokładność ma charakter stopniowalny i z punktu widzenia postępu wiedzy twierdzenie, że te dziedziny badań, które nie poddajq się najbardziej ścisłym procedurom metodologicznym, nie powinny być w ogóle uprawniane, jest po prostu szkodliwe ${ }^{27}$.

W przypadku koncepcji sekularyzacji, nie można mówić o istnieniu jednej, zwartej teorii sekularyzacji, a raczej o grupie teorii, których celem jest określenie znaczenia i roli religii we współczesnych społeczeństwach. Co więcej - jak twierdzi F. Lechner ${ }^{28}$ - nawet po zastosowaniu wycyzelowanych standardów metodologicznych wciąż istnieje duża grupa prac, inspirowanych tradycją weberowska, opartych na wspólnej refleksji teoretycznej ostatniego pokolenia, które zaslugują na miano teorii sekularyzacji.

\section{Problemy związane z weryfikacją teorii}

Jednym z najpoważniejszych zarzutów stała się kwestia empirycznej weryfikacji teoriii ${ }^{29}$. Niewątpliwie wciąż brak jest zgody co do wskaźników, które mogłyby stać się punktem wyjścia weryfikacji teorii i które pozwoliłyby na badanie różnych aspektów procesu sekularyzacji.

\section{a) Wskaźniki religịjności a proces sekularyzaçji}

Symptomatycznym i często przytaczanym wskaźnikiem sekularyzacji jest udział w rytuałach religijnych. W większości krajów europejskich, poczynając od II wojny światowej, zanotowano gwałtowny spadek uczestnictwa w rytuałach oferowanych przez instytucje religijne, co było traktowane jako dowód na istnienie sekularyzacji. Niemniej jednak proces sekularyzacji nie jest tożsamy z zanikiem instytucjonalnych form religijności, ale jest procesem znacznie bardziej złożonym, w związku z tym utożsamianie sekularyzacji z zanikaniem instytucjonalnej religijności wydaje się być uproszczeniem.

Uczestniczenie w rytuałach religijnych może być stosowane jedynie jako jeden ze wskaźników dla pomiaru sekularyzacji na poziomie indywidualnym. War-

\footnotetext{
${ }^{27}$ S. A n d re s k i: Maxa Webera olśnienia i pomylki. Warszawa 1992 s. 43.

${ }^{28}$ F. J. L e c h n e r: The Case Against Secularization, dz. cyt., s. 1114.

${ }^{29}$ J. K. H a d d e n: Toward Desacralizing Secularization Theory, dz. cyt., s. 598.
} 
to jednocześnie podkreślić, iż takie wskaźniki jak uczęszczanie do kościoła czy udział w rytualach religijnych nie sa jednorodnymi fenomenami kulturowymi i statystyczne ich ujęcie kryje w sobie szereg dodatkowych implikacji. Na przyklad zupelnie różne znacznie ma udział w mszy dla katolika a inne dla protestanta. Inną wartość ma uczestniczenie w rytualach religijnych w Irlandii czy Polsce, gdzie katolicyzm przez wieki stanowił ważny element identyfikacji narodowej i gdzie Kościól brał aktywny udzial w walkach o suwerenność, inne zaś w krajach gdzie religia nie odgrywała tak ważnej - $\mathrm{z}$ historycznego punktu widzenia - ro$\mathrm{li}^{30}$. Tak więc wszelkie porównania danych na temat uczestnictwa w rytuałach religijnych muszą być dokonywane bardzo ostrożnie, z uwzględnieniem kontekstu historyczno-kulturowego, a ponadto, należy pamiętać, iż nie oddają one całej złożoności procesu sekularyzacji.

Również dane na temat religijności Europejczyków, stały się argumentem używanym przez krytyków teorii. Wyniki badań prowadzonych w krajach Europy Zachodniej, w latach dziewięćdziesiątych, pokazują iż pomimo spadku praktyk związanych z religijnością instytucjonalna, badani wciąż deklarują wiarę w Boga, a wartości chrześcijańskie - choć często wybiórczo przyswajane - nadal stanowią istotny element ich systemu wartości ${ }^{31}$. Pozostale dane pochodzące $z$ tych samych badań pokazuja jednak, iż religia nie stanowi dla Europejczyków szczególnie istotnego elementu życia, jest zaledwie jednym $z$ wielu elementów systemu normatywnego i nie pełni roli wszechogarniającego i scalającego systemu znaczen ${ }^{32}$.

Dane empiryczne dotyczące religijności instytucjonalnej oraz deklarowanej wiary w dogmaty religijne odnoszą się jedynie sekularyzacji na poziomie indywidualnym. Nie obrazują natomiast całej złożoności procesu sekularyzacji i na ich podstawie nie można ani obalić ani też potwierdzić, iż takowy proces zacho-

${ }^{30}$ B. Wi 1 s o n: The Secularization thesis: Criticisms and rebuttals, dz. cyt., s. 57.

${ }^{31}$ Por. Y. L a $\mathrm{m}$ b e $\mathrm{r} \mathrm{t}$ : The scope and limits of religious functions according to the European Value and ISSP surveys. W: Secularization and Social Integration. Red. R. L a e r m a n s, B. Wils o n, J. B ill i e t. Leuven 1998 s. 213; G. D a v i e: Europe: The Exception That Proves the Rule? W: The Desecularization of the World: Resurgence of Religion and World Politics. Red. P. B e r g e r. Washington 1999 s. 68. Ethics and Public Policy Center \& Michigan. William B. Eerdmans Publishing Company.

${ }^{32}$ Chodzi o dane otrzymane w ramach WVS (World Values Survey) w Europie w 1990 r., dotyczące tego jak ważnym elementem w życiu badanych jest religia. Około $19 \%$ badanych przyznało, iż religia jest bardzo ważnym elementem ich życia. Dla porównania, dla $81 \%$ badanych bardzo ważna jest rodzina, dla $53 \%$ - praca, dla $43 \%$ - przyjaciele i znajomi, a $38 \%$ przyznało, iż bardzo ważnym elementem ich życia jest rozrywka. Religia plasuje się jedynie przed polityka, która jest postrzegana jako ważny element życia przez $8 \%$ badanych. Dane z $W V S$ - za: Y. L a m b e r t: The scope and limits of religious functions according to the European Value and ISSP surveys. W: Secularization and Social Integration. Red. R. L a e r m a s, B. Wils o n, J. B ill i e t. Leuven 1998 s. 213. Leuven University Press. 
dzi. Wskaźniki te równie dobrze mogłyby pozostać na niezmienionym poziomie, albo nawet wzrosnąc w spoleczeństwach, których organizacja i działanie ulegly sekularyzacji.

W związku z powyższym tym bardziej słuszne wydaje się stanowisko K. Dobbelaere'a ${ }^{33}$ czy J. Casanovy ${ }^{34}$, którzy podkreślają wieloaspektowość procesu sekularyzacji. Empiryczne badania wiążą się z koniecznością odpowiedniego zoperacjonalizowania zmiennych dla poszczególnych poziomów czy też aspektów tego procesu, a dodatkowo istotne są powiązania występujące pomiędzy poszczególnymi jego elementami.

\section{b) Związek pomiędzy modernizacją a procesem sekularyzacji}

Kolejny zarzut skierowany przeciwko teorii sekularyzacji odnosił się do jej związku z modernizacja. Jak twierdzi R. Stark ${ }^{35}$, teoria sekularyzacji zawsze była wlączona w szerszy kontekst teoretyczny opisujący zjawisko modernizacji rozumianej jako stopniowy, stały proces. Najogólniej mówiąc przyjmowano za oczywiste istnienie pozytywnego związku pomiędzy współczesnością a sekularyzacją, tak więc zjawiskiem paralelnie towarzyszącym modernizacji miałoby być stopniowe zmniejszanie się znaczenia religii zarówno na poziomie instytucjonalnym jak i na poziomie indywidualnej świadomości ${ }^{36}$. Głównym argumentem świadczacym przeciwko istnieniu takiego związku były dane pochodzace ze Stanów Zjednoczonych, jednego $z$ najbardziej uprzemysłowionych i zmodernizowanych krajów świata, gdzie wciąż obserwuje się wzrost i rozwój roli religii ${ }^{37}$.

Przekonanie, iż sekularyzacja w prostej linii wynika z procesu modernizacji, nie znalazło także potwierdzenia $\mathrm{w}$ świetle procesów zachodzących $\mathrm{w}$ innych

${ }^{33}$ K. D o b b e l a e r e: Towards an Integrated Perspective of the Processes Related to the Descriptive Concept of Secularization, dz. cyt.; T e n ż e: Secularization: An Analysis at Three Levels, Brussels 2002 s. 159;

${ }^{34}$ J. C a s a n ov a: Public Religions in the Modern World. Chicago, London 1994 s. 38 . The University of Chicago Press.

${ }^{35}$ R. S t a r k: Secularization, R.I.P (rest in peace). „Sociology of Religion” 1999 (on-line), issue Fall - dostępny: www.findarticles.com.

${ }^{36}$ P. B e r g e r: Secularity: West and East. Tekst wygłoszony w ramach konferencji Cultural Identity and Modernization in Asian Countries: Proceedings of Kokugakuin University Centennial Symposium organizowanej przez Institute for Japanese Culture and Classics, Kokugakuin University (1983) - dostępny: www.kokugakuin.ac.ip.

${ }^{37}$ Na przykład dane na temat religijności Amerykanów pochodzące $\mathrm{z}$ lat dziewięćdziesiątych wskazują, iż ok. $63 \%$ populacji USA deklaruje wiarę w Boga, a niewiarę zaledwie $2.2 \%$, około $30 \%$ wierzy iż Biblia jest wlaściwym słowem Boga, a około $80 \%$ iż jest to księga napisana pod boskim natchnieniem (D.E. S h e r k a t, C.G. E $1 \mathrm{l}$ i s o n: Recent developments and current controversies in the sociology of religion. „Annual Review of Sociology”. R. 1999: 25 nr 363-394 s. 264). 
kręgach kulturowych. W wielu krajach, w których można zaobserwować renesans islamu - industrializacja i modernizacja odegrały istotną rolę, przynosząc wymierne korzyści najczęściej poprzez wzrost ekonomicznego dobrobytu. Naturalną konsekwencją bylo zaburzenie tradycyjnej religijności, ale efektem modernizacji wcale nie byla sekularyzacja, ale proces wręcz przeciwny, a mianowicie gwałtowna afirmacja purytańskiej wersji własnej religii ${ }^{38}$. Nie wiąże się to jedynie $\mathrm{z}$ restauracją islamskich wierzeń, ale również islamskiego stylu życia, który pod wieloma względami jest otwarcie sprzeczny z ideami charakterystycznymi dla nowoczesności. Chodzi - miedzy innymi - o relacje pomiędzy religią i państwem, rolę i miejsce kobiety w życiu społecznym, moralny kodeks codziennych zachowań, a także granice religijnej i moralnej tolerancji. Religijne odrodzenie nie jest cechą charakterystyczną dla mało zmodernizowanych czy też zacofanych sektorów społeczeństwa, ale występuje w dużych miastach, wśród wykształconych (często zresztą na uczeniach Zachodniej Europy) elit intelektualnych. $\mathrm{Na}$ przykład w Egipcie czy w Turcji to właśnie wykształcone córki zeświecczonych profesjonalistów nakładają chusty i stosują inne sposoby podkreślania skromności muzułmanki ${ }^{39}$.

Konsekwencją krytyki istnienia nierozerwalnego związku pomiędzy modernizacją i sekularyzacją było zrewidowanie tej tezy. Modernizacja, zmieniając całą rzeczywistość życia społecznego, bez watpienia miała doniosły wpływ na miejsce i rolę religii w życiu społecznym, ale jej konsekwencją nie stała się całkowita eliminacja religii, ale raczej zapoczątkowanie ewolucyjnych zmian spolecznych i przeorganizowanie dotychczasowego porządku społecznego ${ }^{40}$. Zasadne wydaje się przypuszczenie, iż w przypadku krajów Europy Zachodniej sekularyzujący wpływ procesów związanych z modernizacją polegał na wzmocnieniu działania tych elementów kultury europejskiej, które zawierały w sobie potencjał sekularyzujący. W odmiennym kontekście kulturowym relacja pomiędzy modernizacji a religią wywolać może całkowicie odmienne efekty, czego dobitnym przykładem jest fundamentalizm islamski.

\section{c) Założenie liniowości przebiegu sekularyzacji}

Mówienie o procesie sekularyzacji wiąże się z założeniem o liniowym i stalym przebiegu tego procesu, co implikuje - $\mathrm{z}$ jednej strony - istnienie $\mathrm{w}$ dawnych czasach spoleczeństw, w których religia odgrywała dominującą rolę, a $\mathrm{z}$ drugiej - powstanie, w wyniku procesu sekularyzacji, społeczeństw calkowicie areligijnych. Zdaniem R. Starka, dokładne badania historyczne i wzrastająca

${ }^{38}$ E. G e 11 n e r: Postmodernizm, rozum i religia. Warszawa 1997 s. 15.

${ }^{39}$ P. B e r g e r: The Desecularization of the World. A Global Overview, dz. cyt., s. 8.

${ }^{40} \mathrm{~S}$. He $11 \mathrm{e}$ m a n s: Secularization in a religiogeneous modernity. W: Secularization and Social Integration, dz. cyt., s. 70. 
ilość danych empirycznych nie pozwalają na utrzymanie takich twierdzeń. Przede wszystkim, należy zrewidować wspólczesne wyobrażenie o roli, jaka religia odgrywała $w$ dawnych czasach. Wielu historyków dowodzi, iż religijność ludzi żyjących w czasach określanych współcześnie wiekiem pobożności niewiele miała wspólnego z żarliwą wiarą ${ }^{41}$. Na przyklad, piszący w jedenastym wieku angielski zakonnik William z Malmesberry uskarżal się że arystokracja rzadko uczęszcza do kościoła, a do tego częstą praktyką bylo odprawiania nabożeństw w sypialniach, podczas których leniwi uczestnicy pozostawali w swoich łożach. Przeciętni ludzie jedynie sporadycznie brali udzial w rytuałach religijnych, nie znali podstawowych prawd wiary. Księża, uwikłani w przyjemności życia ziemskiego, zaniedbywali swe obowiązki związane $\mathrm{z}$ odprawianiem nabożeństw, a wielu z nich wykazywało duży stopień ignorancji w podstawowych sprawach wiary. Badania dotyczace istniejących w tamtym okresie w Europie parafii pokazuja, iż były one zbyt male, aby obją́ swym zakresem i posługą ludność przynależną do ich rejonu. Brak kleru byl bolączką większości parafii, z problemem tym borykało się na przykład około 25\% parafii diecezji Strasburga i około 80\% parafii diecezji Genewy w szesnastowiecznej Francji ${ }^{42}$. Przytoczone powyżej oraz inne podobne dane nasuwają wniosek, iż nie można mówić o upadku religijności w stosunku do rzekomego historycznego wieku pobożności, ponieważ nigdy nie miał on w istocie miejsca, a zatem przekonanie o postępującej sekularyzacji jest nieuprawnione. Zwolennicy teorii sekularyzacji zostali oskarżani o blędną interpretacje danych historycznych i skonstruowanie mitologicznej rzeczywistości, która nigdy w przeszłości nie istniała.

Przytoczone powyżej argumenty pomijają kilka istotnych założeń dotyczących sekularyzacji, a mianowicie, że nie jest to proces tożsamy z dechrystianizacją i nie odnosi się on jedynie do wzorów zachowań jednostkowych, ale również do zasad i założeń, na których spoleczeństwo jest zorganizowane i w zgodzie $\mathrm{z}$ którymi funkcjonuje. Niewątpliwie prawdą jest, iż nie wszyscy Europejczycy byli w średniowieczu czy renesansie żarliwymi chrześcijanami, ale faktem jest, iż żyli oni w świecie, w którym religijna, czy też metafizyczna interpretacja rzeczywistości była dominująca, gdzie właściwie nie istniała świecka kultura, a legitymizacja strukturalnej organizacji społeczeństw opierała się na przesłankach religijnych ${ }^{43}$.

\footnotetext{
${ }^{41}$ Por. D o u g la s - za: F. J. Le c h n e r: The Case Against Secularization: A Rebuttal. Social Forces, dz. cyt., s. 1106.

${ }^{42}$ R. S t a r k: Secularization, R.I.P (rest in peace), dz. cyt., dostępny: www.findarticles.com.

${ }^{43}$ B. Wils o n: The Secularization thesis: Criticisms and rebuttals, dz. cyt., s. 53.
} 


\section{d) Nowe ruchy religijne - potwierdzenie czy zaprzeczenie?}

Przeciwko tezie o sekularyzacji świadczyć ma również pojawienie się we wspólczesnej Europie licznych nowych ruchów religijnych, czerpiących z różnych tradycji religijnych bądź też odwolujących się do magicznych i okultystycznych źródeł. Istnieje również szeroka gama ruchów określanych mianem human potential movements, których misja jest poszerzenie możliwości ludzi decydujących się na przystapienie do nich ${ }^{44}$. Pomijając różnorodność formy i struktury nowych ruchów religijnych, zasięg tego zjawiska nie jest aż tak znaczny, aby można było mówić o odwróceniu czy też zahamowaniu procesu sekularyzacji. Co więcej, fakt pojawienia się nowych ruchów religijnych w Europie jest dla niektórych zwolenników tezy o sekularyzacji dowodem na istnienie, używając terminologii ${ }^{45}$, sekularyzacji na poziomie mezo. Pluralizacja religii, będąca efektem dezintegracji chrześcijańskiej kolektywnej świadomości Zachodu, zaowocowala pojawieniem się wielu alternatywnych propozycji i powstaniem „rynku religii”, które wspólzawodniczą ze sobą w celu zdobycie nowych wyznawców. Istnienie wielości propozycji wiąże się z relatywizacją ich przesłania. Co więcej, nowe propozycje - jak zauważa T. Luckmann ${ }^{46}$ - charakteryzuja się niższym poziomem transcendencji, pozostając na poziomie życia codziennego.

Wynikiem krytyki teorii sekularyzacji nie było jej zarzucenie, ponieważ jak twierdzą nawet jej najgorliwsi przeciwnicy - jest ona wciąż użyteczna, ale zrewidowanie wielu jej postulatów. Współcześnie nie twierdzi się, iż w wyniku modernizacji i postępu powstaną totalnie areligijne społeczeństwa, nie wyklucza się także istnienia religijnych ludzi. Sekularyzacja jest rodzajem zmiany spolecznej, w wyniku której religia traci znaczenie dla funkcjonowania społeczeństwa i dla indywidualnego życia jednostek. Nie oznacza to więc całkowitego zaniku religii, a raczej zmianę jej miejsca, roli, a często również formy. Jednocześnie odrzucone zostało założenie, iż jest to proces o charakterze jednokierunkowym, przyjmując, iż możliwe są okresy rewitalizacji religii, czy - używając popularnego współcześnie pojęcia - resakralizacji. Wielu teoretyków skłania się ku tezie, iż we współczesnym świecie procesy te współistnieją ${ }^{47}$.

${ }^{44} \mathrm{M} . \mathrm{H}$ a m i $1 \mathrm{t}$ o n: The sociology of religion: theoretical and comparative perspectives, $\mathrm{dz}$. cyt., s. 207.

${ }^{45}$ K. D o b b e l a e r e' a: Towards an Integrated Perspective of the Processes Related to the Descriptive Concept of Secularization, dz. cyt., dostępny: www.findarticles.com.

${ }^{46}$ T. L u c k m a n n: Shrinking transcendence, expanding religion? "Sociological Analysis". R. 50: 1990 s. $127-138$

${ }^{47}$ L. Wo o d h e a d, P. H e e l a s (red.): Religion in Modern Times. Oxford 2000 s. 308. 
Paradygmat sekularyzacji ukształtowany został w warunkach europejskich i swoje zalożenia i przewidywania opieral na zjawiskach, zachodzacych $w$ tej tradycji kulturowej. Wielu teoretyków, zapominając o europejskich korzeniach tego podejścia, traktowalo je jako uniwersalny wzór zmiany, obowiązujacy dla każdego społeczeństwa, które wkroczy na drogę modernizacji, niezależnie od różnic historyczno-kulturowych. Stopniowe nagromadzenie danych pochodzących z różnych rejonów świata obaliło tezę, iż sekularyzacja jest wzorem uniwersalnym. Niewątpliwie proces sekularyzacji jest zauważalnym faktem w europejskim kręgu kulturowym, niemniej jednak stanowi raczej wyjątek niż regułę ${ }^{48}$. Uniwersalna wartość modelu sekularyzacji została zatem podważona.

\section{Próba podsumowania - sekularyzacja czy sakralizacja?}

Przedwczesne wydaje się mówienie o upadku starego paradygmatu i powstaniu nowego. Radykalni zwolennicy teorii sekularyzacji postrzegają sytuację występująca w Zachodniej Europie jako normę, a przypadek Stanów Zjednoczonych traktują jako wyjątek od reguły, podczas gdy jej przeciwnicy kwestie normy i wyjątków od niej postrzegają w dokładnie odwrotny sposób.

Wobec wzrastającej liczby danych empirycznych, które pozostawały w sprzeczności z przewidywaniami teorii, pojawiło się pytanie, czy paradygmat ten znalazł się w punkcie, gdy - używając koncepcji rewolucji naukowych Kuhn'a stopniowe nagromadzenia anomalii wywoluje kryzys intelektualny, którego efektem jest zmiana paradygmatu badawczego ${ }^{49}$. Niewątpliwie bodźcem do podjęcia tego typu rozważań był, w pierwszej kolejności, przypadek Stanów Zjednoczonych, który nie mieścił się w oferowanych przez teorię sekularyzacji ramach.

Na bazie krytyki modelu sekularyzacji powstały nowe koncepcje, wśród których najbardziej wplywowa jest teoria religii zaproponowana przez R. Starka i W. Bainbridge' ${ }^{50}$, która - jak piszą jej zwolennicy - wyrosła na gruncie doświadczeń amerykańskich i wynikała $z$ „całkowicie niezależnego widzenia inspirowanego przez historię Ameryki". Jest ona ponadto całkowicie oparta na danych empirycznych i wolna od "założeń przyjmujących co powinno się zdarzyć"

- co zdaniem jej sympatyków - charakteryzowało „zmitologizowaną" teorię

\footnotetext{
${ }^{48}$ G. D a vi e: Prospects for religion in The Modern World, dz. cyt., s. 78 .

${ }^{49} \mathrm{~J}$. H a d d e n: Religion and the quest for meaning and order: old paradigms, new realities. „Sociological Focus”. R. 28: 1995 nr 1.

${ }^{50}$ R. S t a r k, W.S. B a i n b r i d g e: Teoria religii. Kraków 2000.
} 
sekularyzacji ${ }^{51}$. Ta nowa propozycja próbuje też wyjaśnić powód oraz sposób pojawiania się, wzrostu i upadku organizacji religijnych i systemów wierzeń.

Propozycja Starka i Bainbridge'a spotkała się z pozytywnym przyjęciem, szczególnie wśród krytyków teorii sekularyzacji. Jej niewątpliwą zaletą jest dobrze udokumentowane zakorzenienie $w$ danych empirycznych oraz dedukcyjna postać. Niemniej jednak wiele zastrzeżeń budzi sprowadzenie zachowań ludzkich do racjonalnej kalkulacji zysków i nagród. Jednocześnie - mimo iż model ten doskonale pasuje do realiów amerykańskich - jego moc predykcyjna jest dużo słabsza $\mathrm{w}$ odniesieniu do zjawisk, jakie maja miejsce we współczesnej Europie.

Jednym z priorytetowych problemów dyskusji na temat sekularyzacji jest rozróżnienie pomiędzy kwestią występowania bądź też nie procesu sekularyzacji, a kwestią zbudowania takiego modelu teoretycznego, który byłby $w$ stanie uchwycić uwarunkowania, przebieg i efekt tego procesu. Teoretycy są raczej zgodni iż proces sekularyzacji ma miejsce w Europie, natomiast problem pojawia się, gdy dyskusja dotyka kwestii modelu adekwatnego do opisania tej rzeczywistości.

Debata na temat sekularyzacji wciąż wywołuje żywe emocje wśród jej zwolenników i krytyków, zaś dyskusje i krytyka przyczyniły się do zrewidowania licznych założeń dotyczących procesu sekularyzacji. Pomimo iż wiele zarzutów skierowanych pod adresem samej koncepcji sekularyzacji jest słusznych, odrzucenie całego podejścia wydaje się zbyt pośpieszne, chociażby dlatego, iż alternatywne propozycje teoretyczne niezbyt dobrze radza sobie $\mathrm{z}$ przypadkiem europejskim. Jednym $z$ efektów krytyki jest odrzucenie postrzegania sekularyzacji jako uniwersalnego procesu rozwoju religii we współczesnym świecie. Wobec różnorodności poszczególnych tradycji religijnych i ich przejawów w życiu spolecznym, niemożliwe do utrzymania jest twierdzenie o istnieniu jednego uniwersalnego wzoru zmiany i przyjmowanie jednego uniwersalnego podejścia teoretycznego, które służylby jako model badawczy dla wszystkich tradycji religijnych. W związku z tym, bardziej zasadne wydaje się mówienie o ograniczonym zasięgu modelu sekularyzacji i zastosowanie go do rzeczywistości europejskiej. Zawężenia stosowalności koncepcji nie zwalnia z konieczności dalszej dyskusji na temat poszczególnych jej elementów. Niewątpliwe istnieje konieczność wypracowania wskaźników, odnoszących się do różnych aspektów procesu sekularyzacji, które pozwoliłyby na empiryczną weryfikację założeń modelu, co wymaga dalszej debaty i badań.

${ }^{51} \mathrm{~J} . \mathrm{H}$ a d d e $\mathrm{n}$ : Religion and the quest for meaning and order: old paradigms, new realities, dz. cyt., s. 85 . 
Należy również pamiętać, iż współczesny europejski wzór religijny nie jest rzeczywistością statyczną. Proces sekularyzacji jest dynamicznym procesem zmiany i możliwe jest zaistnienie paralelnych procesów sekularyzacji i resakralizacji. Już dziś można obserwować aktywnie i prężnie rozwijający się w Europie islam, w odniesieniu do którego trudno mówić o sekularyzacji. Pozostaje więc pytaniem otwartym w jakim kierunku będą przebiegać dalsze zmiany. Pytanie to wydaje się być szczególnie istotnym w kontekście wzrastającej wielokulturowości i wzrastającego zróżnicowania religijnego Europejczyków. 
